\title{
КАРДИОПРОТЕКТОРНОЕ ДЕЙСТВИЕ ПРОИЗВОДНЫХ ГАМК И ГЛУТАМИНОВОЙ КИСЛОТЫ ПОСЛЕ ЭКСПЕРИМЕНТАЛЬНОЙ ХРОНИЧЕСКОЙ АЛКОГОЛЬНОЙ ИНТОКСИКАЦИИ
}

\section{М.В. Кустова', В.Н.Перфилова', И.И.Прокофьев², И.Н. Тюренков'}

${ }^{1}$ Кафедра фармакологии и фармации ИНМФО Волгоградский государственный медицинский университет, 400087, Россия, Волгоград, улица Новороссийская, 39.

${ }^{2}$ Кафедра судебной медицины, Волгоградский государственный медицинский университет, 400049, Россия, Волгоград, улица Рокоссовского, 1г.

DOI: 10.19163/MedChemRussia2021-2021-107

E-mail: kustova13@gmail.com

Хроническая алкогольная интоксикация вызывает окислительный стресс, митохондриальную и эндотелиальную дисфункцию, апоптоз кардиомиоцитов, электролитные нарушения, что приводит к снижению сократимости миокарда и формированию тяжелых сердечно-сосудистых заболеваний. Существующие методы лечения алкогольного поражения миокарда малоэффективны, поэтому поиск новых лекарственных средств является актуальным. Производные ГАМК и глутаминовой кислоты улучшают инотропную функцию сердца стрессированных животных, обладают кардиопротекторным действием при ишемии миокарда. В этой связи было изучено влияние соединения РГПУ-238 и РГПУ-260 на сократительную функцию миокарда у крыс-самок после хронической алкогольной интоксикации (ХАИ), вызванной заменой питьевой воды на 10\% раствор этанола в течение 24 недель [1]. Исследуемые соединения и препарат сравнения милдронат вводили после отмены алкоголя, внутрибрюшинно один раз в день в течение 14 дней. Влияние веществ на функциональные резервы сердца изучали с использованием нагрузочных тестов: увеличенияпреднагрузки, пробы на адренореактивность, максимальной изометрической нагрузки [2].

Выявлено, что ХАИ вызывает снижениесократительной функции миокарда, на что указывают более низкие приросты скоростей сокращения и расслабления миокарда, ЛЖД и МИФС по сравнению с интактными животными. У самок, которым после ХАИ вводили исследуемые соединения и препарат сравнения милдронат, наблюдали более высокие приросты этих показателей по сравнению с животными контрольной группы, что свидетельствует об улучшении состояния инотропных резервов сердца крыс опытных групп.

\section{Литература}

[1] Крыжановский, С. А., Колик, Л. Г., Цорин И.Б. и др. Бюллетень экспериментальной биологии и медицины. 2017, 163(5), 582-586.

[2] Тюренков И. Н., Перфилова В.Н.Руководство по проведению доклинических исследований лекарственных средств.2012,375-384.

$$
-107-
$$

